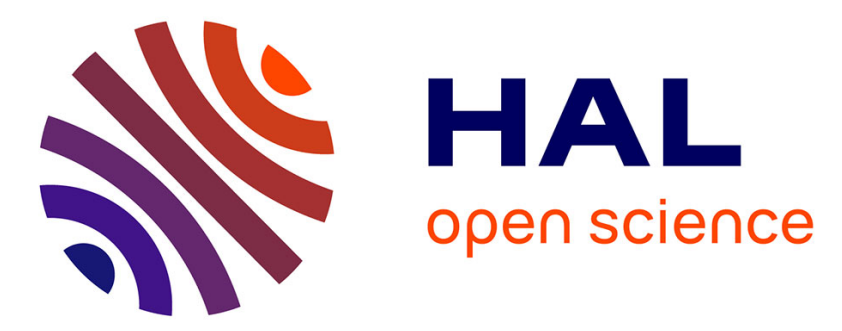

\title{
Electroactivity of superoxide anion in aqueous phosphate buffers analyzed with platinized microelectrodes
}

Pauline Lefrancois, Fanny Girard-Sahun, Vasilica Badets, Franck Clement, Stéphane Arbault

\section{- To cite this version:}

Pauline Lefrancois, Fanny Girard-Sahun, Vasilica Badets, Franck Clement, Stéphane Arbault. Electroactivity of superoxide anion in aqueous phosphate buffers analyzed with platinized microelectrodes. Electroanalysis, 2020, 10.1002/elan.202060456 . hal-03014128

\section{HAL Id: hal-03014128 \\ https://hal.science/hal-03014128}

Submitted on 5 Jan 2021

HAL is a multi-disciplinary open access archive for the deposit and dissemination of scientific research documents, whether they are published or not. The documents may come from teaching and research institutions in France or abroad, or from public or private research centers.
L'archive ouverte pluridisciplinaire HAL, est destinée au dépôt et à la diffusion de documents scientifiques de niveau recherche, publiés ou non, émanant des établissements d'enseignement et de recherche français ou étrangers, des laboratoires publics ou privés. 


\title{
Electroactivity of Superoxide Anion in Aqueous Phosphate Buffers Analyzed with Platinized Microelectrodes
}

\author{
Pauline Lefrançois ${ }^{+},{ }^{[a, c]}$ Fanny Girard-Sahun ${ }^{+},{ }^{[a, b, c]}$ Vasilica Badets, ${ }^{[a, c]}$ Franck Clément, ${ }^{[b]}$ and \\ Stéphane Arbault*[a]
}

\begin{abstract}
The reactivity of platinized ultramicroelectrodes (Pt-black UMEs) towards superoxide anion $\mathrm{O}_{2}{ }^{--}$, an unstable Reactive Oxygen Species (ROS), and its relatives, $\mathrm{H}_{2} \mathrm{O}_{2}$ and $\mathrm{O}_{2}$, was studied. Voltammetric studies in PBS demonstrate that Pt-black UMEs provide: i) a wellresolved reversible redox signature for $\mathrm{O}_{2}{ }^{-}$detected in both alkaline and physiological buffers (pH 12 and 7.4);
\end{abstract}

ii) irreversible oxidation and reduction waves for $\mathrm{H}_{2} \mathrm{O}_{2}$ at $\mathrm{pH}$ 7.4. The oxygen reduction reaction (ORR) at Pt-black surfaces solely yields $\mathrm{H}_{2} \mathrm{O}_{2}\left(2\right.$ electrons $\left./ 2 \mathrm{H}^{+}\right)$at physiological pH. Consequently, Pt-black UMEs allow to sense different ROS including superoxide anion for future biomedical or physico-chemical investigations.

Keywords: superoxide $\cdot$ ultramicroelectrode $\cdot$ hydrogen peroxide $\cdot$ reactive oxygen species $\cdot$ cold atmospheric plasma

\section{Introduction}

The Reactive Oxygen and Nitrogen Species (ROS, RNS, merged as RONS) are known to play crucial roles in multiple biological processes, including innate immunity, redox signaling, vasodilation, neuro-modulation, carcinogenesis, etc. [1-5]. ROS are produced by aerobic cells owing to diverse enzymatic systems (NADPH oxidase, Xanthine oxidase, etc.) and by side reactions such as during the reduction the conversion of dioxygen $\left(\mathrm{O}_{2}\right)$ to water by the mitochondrial respiratory chain (semiquinone intermediate reduction). Bioactive ROS mostly comprise superoxide anion $\left(\mathrm{O}_{2}{ }^{--}\right)$, hydrogen peroxide $\left(\mathrm{H}_{2} \mathrm{O}_{2}\right)$, hydroxyl radical $\left(\mathrm{HO}^{\bullet}\right)$ and singlet oxygen $\left({ }^{1} \mathrm{O}_{2}\right)$ both produced under the presence of catalysts. The radicals are by nature very reactive and unstable in physiological conditions: the lifetime of $\mathrm{HO}^{\bullet}$ is about $1 \mathrm{~ns}$ [6]; $\mathrm{O}_{2}{ }^{--}$disproportionation occurs at rate constants of $5.10^{-5} \mathrm{M}^{-1} \cdot \mathrm{s}^{-1}$ and $10^{-9} \mathrm{M}^{-1} \cdot \mathrm{s}^{-1}$ at $\mathrm{pH} 7.4$, either spontaneously or when catalyzed by superoxide dismutases (SOD), respectively. The disproportionation follows the reaction [7]:

$$
2 \mathrm{O}_{2}^{\bullet-}+2 \mathrm{H}^{+} \rightarrow \mathrm{O}_{2}+\mathrm{H}_{2} \mathrm{O}_{2}
$$

$\mathrm{H}_{2} \mathrm{O}_{2}$ is stable over hours in aqueous solution at $\mathrm{pH} 7.4$ and is degraded in presence of metal ion traces (iron or copper ions) [8,9], and catabolic enzymes, namely catalase and peroxidases. The ROS can be involved further in reactions with nitrogen derivatives including nitric oxide $\left(\mathrm{NO}^{\bullet}\right)$ to form highly reactive, nitrosative and nitrative species, such as the peroxynitrite anion $\left(\mathrm{ONOO}^{-}\right)$, nitrogen dioxide $\left(\mathrm{NO}_{2}\right)$ and the nitrosonium cation $\left(\mathrm{NO}^{+}\right)[10,11]$.

The RONS can also be produced by other physicochemical processes involved in atmospheric pollution or developed for sterilization, chemical reactions, etc. [12-
15] This is the case of Cold Atmospheric Plasmas (CAPs), which are complex ionized gases composed of electrons, neutral atoms or molecules, ions and excited atoms or molecules. CAPs can be produced experimentally at atmospheric pressure and room temperature and are used for a large range of biomedical applications: skin regeneration, skin tumor treatment, teeth whitening, etc. [15-17]. The majority of the observed biological effects induced by CAPs are due to RONS.

For these reasons, there is still a large interest for the detection and quantification of the biologically active RONS. However, this remains a challenge, mainly because their short lifetime does not allow enough accumulation. Therefore, their subsequent detection by analytical techniques is very limited [18]. This is partic-

[a] P. Lefrançois, ${ }^{+}$F. Girard-Sahun, ${ }^{+}$V. Badets, S. Arbault Univ. Bordeaux, Bordeaux INP

CNRS UMR 5255, ISM, groupe NSysA

33400 Talence, France

E-mail: stephane.arbault@u-bordeaux.fr

[b] F. Girard-Sahun, ${ }^{+}$F. Clément

UPPA, IPREM

CNRS UMR 5254

2 avenue Président Angot

64000 Pau, France

[c] P. Lefrançois, ${ }^{+}$F. Girard-Sahun, ${ }^{+}$V. Badets

Chemistry Department, University of Antwerp

Campus Drie Eiken Universiteitsplein 1, Belgium.

and

Department of Biochemistry, University of Groningen

Groningen Biomolecular Sciences and Biotechnology Institute Nijenborgh 4, 9747 AG Groningen, The Netherlands and

University of Strasbourg, Chemistry Institute

UMR CNRS 7177

4 rue Blaise Pascal, CS 90032, 67081 Strasbourg cedex, France

$\left.{ }^{+}\right]$These two authors contributed equally to the paper. 
ularly true when RONS are produced in aqueous buffers under CAPs exposure. We have recently reported the electrochemical detection of kinetically stable species, including $\mathrm{H}_{2} \mathrm{O}_{2}, \mathrm{NO}_{2}^{-}$and $\mathrm{NO}_{3}{ }^{-}$species, accumulating in PBS during its constant exposure to a CAP [19]. The detection in plasma-treated solutions of $\mathrm{H}_{2} \mathrm{O}_{2}$ at concentrations reaching hundreds of $\mu \mathrm{M}[20,21]$, as well as the detection of peroxynitrite $\mathrm{ONOO}^{-}$(tens of $\mu \mathrm{M}$ ) by UVvisible absorption spectroscopy $[19,20]$ have strongly suggested the prior existence of superoxide in these solutions. Unfortunately, the hypothesis was not confirmed since the direct detection of $\mathrm{O}_{2}{ }^{--}$in aerobic and physiological conditions remains very challenging. The objective of the present work is to propose an electroanalytical approach to go beyond this limitation.

A wide variety of electrochemical sensors for the detection of RONS have been reported, particularly based on redox enzymes (peroxidase, catalase, etc.) [2225]. The specific detection of $\mathrm{O}_{2}^{--}$was shown by using cytochrome $c$-modified gold electrodes [26]. Ultramicroelectrodes (UMEs) which carbon or platinum surface could be modified by platinum nanostructured rough deposits, quoted as platinum black (Pt-black coating) were later developed $[27,28]$. Their electrocatalytic properties provide UMEs with the ability to selectively detect several ROS and RNS [29-31]. In addition, platinized UMEs are particularly useful for sensitive measurements in micrometric volumes including at single cells [32] and in microsystems (channels and chambers) [33-36]. Pt-black UMEs display a fast response-time and offer linear current variations over large concentration domains of e.g. $\mathrm{H}_{2} \mathrm{O}_{2}$ (from tens of $\mathrm{nM}$ to $\mathrm{mM}$ ) [37]. In addition, we recently observed that Pt-black UMEs allow to detect superoxide anion in alkaline conditions (PBS at $\mathrm{pH} 12$ ) [37].

The aim of this paper is to further investigate the electroanalysis of $\mathrm{O}_{2}{ }^{--}$as function of the $\mathrm{pH}$ in phosphate buffers ( $\mathrm{pH} 12$ to 7.4). The reactivity of Pt black UMEs towards the by-products of superoxide disproportionation, $\mathrm{H}_{2} \mathrm{O}_{2}$ and $\mathrm{O}_{2}$, was studied at $\mathrm{pH} 7.4$ for each species and in solutions containing both species. We demonstrate that superoxide and hydrogen peroxide can be detected selectively at different potentials in aerobic PBS. Finally, we show the direct monitoring of superoxide, when produced and accumulating in alkaline PBS exposed to a CAP. Thus, this study will serve as a reference work to decipher on the complex production of RONS by CAPs and biological sources as well.

\section{Experimental}

\subsection{Chemicals}

PBS solution at $10 \mathrm{mM}, \mathrm{pH} 7.4$, was prepared by dissolving the content of a ready-made salt mix (ref. P5368, Sigma Aldrich) in $1 \mathrm{~L}$ of pure milliQ water (Millipore, Integral 3, $0.22 \mu \mathrm{m}$ MilliPak filter). PBS solution at $10 \mathrm{mM}$ and $\mathrm{pH} 12$ was prepared by additions of $1 \mathrm{M}$ sodium hydroxide in PBS pH $7.4(10 \mathrm{mM})$. Solutions of $\mathrm{H}_{2} \mathrm{O}_{2}$ were prepared by dilutions of a $100 \mathrm{mM}$ stock solution in PBS, freshly prepared from a $9.8 \mathrm{M}$ commercial solution ( $30 \%$ hydrogen peroxide, Sigma). A stock solution of superoxide was prepared by solubilizing potassium dioxide (ref. 278904 Sigma Aldrich) in ice-cold $30 \mathrm{mM} \mathrm{NaOH}$. The obtained concentration was calculated following a protocol reported elsewhere [37,38]. Briefly, a $\sim 1 \mathrm{M}$ superoxide stock solution was prepared, which corresponds to $5 \mathrm{MKO}_{2}$ (Caution! Potassium superoxide reacts violently with water). The 1:5 ratio was proposed by Marklund et al. and originates from the high reactivity of $\mathrm{O}_{2}{ }^{\bullet-}$ [17]. Superoxide dismutase (ref. S5639, Sigma Aldrich) stock solution was prepared at $30 \mathrm{kU} \cdot \mathrm{mL}^{-1}$ in PBS $(10 \mathrm{mM}, \mathrm{pH} 7.4)$, aliquoted and stored at $-20^{\circ} \mathrm{C}$. Aliquots were thawed prior to use.

\subsection{Fabrication and Surface Modification of UMEs}

UMEs were prepared by heat-sealing $\mathrm{Pt}$ micro-wires (25 $\mu \mathrm{m}$ diameter, $99 \%$ purity, Goodfellow) in glass capillaries (1 mm diameter, WPI) (Figure 1). Each UME was polished with coarse- and fine-grade polishing papers before use or further surface modification. Platinum-black electrodeposition (Pt-black) on UME surface was obtained in potentiostatic mode, at a potential of $-0.06 \mathrm{~V}$ vs. $\mathrm{Ag} / \mathrm{AgCl} / \mathrm{NaCl} 3 \mathrm{M}$, by reducing a hydrogen hexachloroplatinate solution (115 mM in $10 \mathrm{mM}$ PBS, pH 7.4 with $0.76 \mathrm{mM}$ of lead acetate). The electrodeposition was stopped when the total reduction charge reached $\sim 0,1 \mu \mathrm{C} \mu \mathrm{m}^{-2}$ (37 $\mu \mathrm{C}$ total charge), which corresponds to a previously defined optimum for the detection of hydrogen peroxide by Pt-black UMEs [39] (Figure 1C).

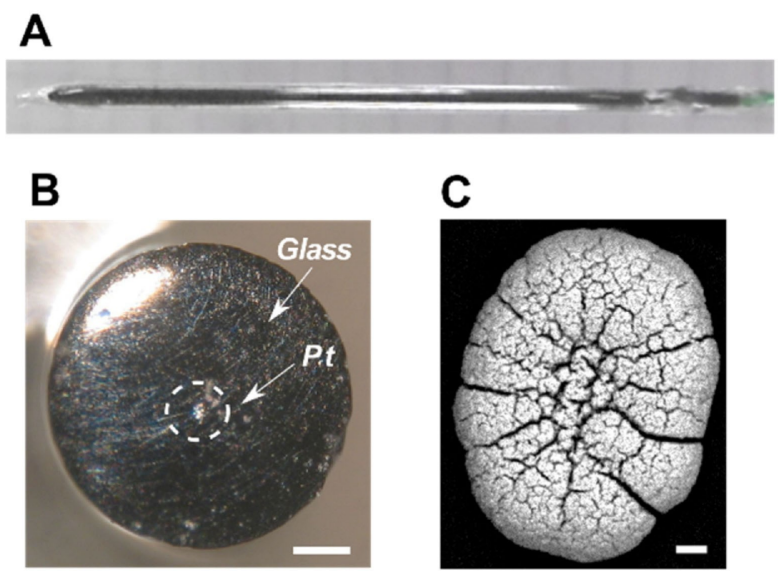

Fig. 1. Multiscale view of a platinized platinum ultramicroelectrode (Pt wire $\varnothing 25 \mu \mathrm{m}$, total external diameter $1 \mathrm{~mm}$ ) used as $\mathrm{WE}$ in the experiments. (A) Side view of the whole electrode. (B) Top view of the electrode. The Pt wire (encircled) is sealed in a glass capillary. Scale bar $=100 \mu \mathrm{m}$. (C) Platinum-black nanostructure observed by scanning electron microscopy. Scale bar= $5 \mu \mathrm{m}$. 


\subsection{Electrochemical Measurements}

\subsubsection{Cyclic Voltammetry}

All the characterizations of ROS electrochemical responses were achieved by cyclic voltammetry (CV). Experiments were performed using a gas tight electrochemical cell comprising typically $20 \mathrm{~mL}$ of solution. The three electrodes (WE: Pt-black UME, REF: $\mathrm{Ag} / \mathrm{AgCl}$ wire, $\mathrm{CE}$ : Pt wire) were inserted in the septum stopper of the electrochemical cell. When needed, a slight gas flow was injected using a needle for 7-10 min to saturate the solution with either nitrogen or oxygen. The effective solution saturation in $\mathrm{N}_{2}$ or $\mathrm{O}_{2}$ was estimated by following the signal evolution in $\mathrm{CV}$. When no modification of the solubilized gas was performed, we will quote the experimental condition as 'aerated' or will not specify it. Measurements were obtained in steady-state conditions at a $20 \mathrm{mVs}^{-1}$ scan rate, within different potential ranges, specified for each experiment. All the potentials are computed with respect to an $\mathrm{Ag} / \mathrm{AgCl}$ (saturated $\mathrm{KCl}$ solution)-type reference electrode. All electrochemical measurements were carried out using a bipotentiostat (BioLogic, VSP-300, EC-Lab software) equipped with low current modules and filters set at $5 \mathrm{~Hz}$. The analyses were performed in a Faraday cage to minimize the electric noise.

\subsubsection{Collector-generator Experiment}

For collector-generator experiments, we prepared platinized carbon fiber-based UMEs, which outer diameter was smaller and easier to manipulate. To prepare a carbon UME, an individual carbon fiber (10 $\mu \mathrm{m}$ diameter, Cytec Engineered Materials, ref. Thornel P-55S) was inserted in a glass capillary (1 mm diameter, WPI) and sealed by heat pulling (Narishige, model PC10). The protruding part of carbon fiber was insulated by electrochemical deposition of poly-oxyphenylene (see [40] for details). The tip of the insulated carbon fiber was then polished at a $45^{\circ}$ angle on a microgrinder (WPI, model $48000,1 \mu \mathrm{m}$ roughness) to expose a clean, elliptical carbon surface. The polished carbon surface was then platinized following the same procedure as for Pt UMEs described in the previous section.

In these experiments, two different electrochemical measurements were performed at each UME, by using cyclic voltammetry on one side (from +0.16 to $-0.34 \mathrm{~V}$ ) and chrono-amperometry at a fixed potential $(+0.35 \mathrm{~V})$ on the other one, or chrono-amperometry at a different potential on each UME. A three-electrode electrochemical configuration was used for each UME, composed of the platinized carbon UME as working electrode, an AgCl-coated-Ag wire as pseudo-reference electrode (REF; 1 mm diameter) and a Pt wire as counter electrode (CE; $1 \mathrm{~mm}$ diameter). Each UME was coupled to an individual $\mathrm{CE}$ whereas a common REF was used for the two UMEs.
An inverted microscope (Leica STP 6000, 20x objective) was used to observe the position of one UME to the other. The experiment was carried out on a clean microscope slide on which a rectangular PDMS frame was placed. All the electrodes were positioned in $1 \mathrm{~mL}$ of PBS solution (10 mM, pH 7.4, Sigma). The position of the two UMEs was set with two micromanipulators (ThorLabs, PCS-5200) facing each other at a few micrometers distance.

\subsubsection{Analysis in Solution Exposed to a Cold Atmospheric Plasma}

The plasma setup used in these experiments has been described previously [20,21]. Briefly, a surrounding gas device allows to control the gaseous environment of the gas phase (plasma). We used helium $\mathrm{He}$ as the working gas (1.67 slm rate) and the environment gas was composed of $100 \% \mathrm{~N}_{2}(0.03 \mathrm{slm}$ rate; Linde, $99.9995 \%)$, for a total gas flow of $1.7 \mathrm{slm}$. The production of ionization waves was achieved using a pulsed high voltage power supply with rise and fall times of pulses in the order of $100 \mathrm{~ns}$. The electrical parameters are as following: positive pulses of $7.5 \mathrm{kV}$ amplitude, $1 \mu \mathrm{s}$ duration, $10 \mathrm{kHz}$ repetition frequency and $1 \%$ duty cycle. $6 \mathrm{~mL}$ of PBS at $\mathrm{pH} 11$ was exposed to the plasma in a homemade quartz cuvette (external diameter $44 \mathrm{~mm}$, inner diameter $41 \mathrm{~mm}$, depth $40 \mathrm{~mm}$ ). A distance of $20 \mathrm{~mm}$ was fixed between the end tube of the plasma device and the solution. Moreover, the cuvette was placed over a metallic support connected to the ground in order to ensure a constant potential to the sample. The working WE Pt-black UME, as well as the REF and CE electrodes, were inserted within two insulated-earthed containers in order to protect them from the surrounding high electric field transported by the plasma. Each container was made of a quartz glass capillary (few centimeters long, internal diameter 7$9 \mathrm{~mm}$ ) covered by a conductive sheath connected to the ground of the building, and covered by an insulating layer of retractable polymer sheath for power cables. Containers (first with WE and REF; second with $\mathrm{CE}$ ) were placed in the PBS solution and continuous CV was performed at the WE before and during the solution exposure by the CAP to monitor the generation of ROS including superoxide.

\section{Results and Discussion}

\subsection{Redox Behavior of Hydrogen Peroxide and Oxygen in PBS pH 7.4}

\subsubsection{Redox Behavior of $\mathrm{H}_{2} \mathrm{O}_{2}$}

First, the electrochemical reactivity of Pt-black UMEs was analyzed in $\mathrm{H}_{2} \mathrm{O}_{2}$ solutions. We previously reported the characterization of the oxidation waves of hydrogen peroxide on these surfaces for large concentrations (up to $100 \mathrm{mM}$ ) and positive potential ranges [37]. Herein, we focused on lower concentrations $(<1 \mathrm{mM})$ in order to get 
closer to the range of concentrations measured in PBS exposed to CAPs [20,21]. Cyclic voltammetry analyses were performed between $-0.2 \mathrm{~V}$ and $+0.5 \mathrm{~V}$, allowing to observe both the reduction and oxidation processes for $\mathrm{H}_{2} \mathrm{O}_{2}$. Results are depicted on Figure 2. We observe in these conditions two well separated, irreversible oxidation and reduction waves, which plateaus start around $+0.35 \mathrm{~V}$ vs. $\mathrm{Ag} / \mathrm{AgCl}$ and $-0.15 \mathrm{~V}$ vs. $\mathrm{Ag} / \mathrm{AgCl}$, respectively. We hypothesize that the oxidation reaction of $\mathrm{H}_{2} \mathrm{O}_{2}$ follows the equation (Equation 2):

$$
\mathrm{H}_{2} \mathrm{O}_{2} \rightarrow \mathrm{O}_{2}+2 \mathrm{H}^{+}+2 e^{-}
$$

(redox couple $\mathrm{O}_{2} / \mathrm{H}_{2} \mathrm{O}_{2}$ ), while the reduction of $\mathrm{H}_{2} \mathrm{O}_{2}$ follows (Equation 3):

$$
\mathrm{H}_{2} \mathrm{O}_{2}+2 \mathrm{H}^{+}+2 e^{-} \rightarrow 2 \mathrm{H}_{2} \mathrm{O}
$$

(redox couple $\mathrm{H}_{2} \mathrm{O}_{2} / \mathrm{H}_{2} \mathrm{O}$ ). Indeed, the amplitudes of both waves are directly dependent on the concentration of $\mathrm{H}_{2} \mathrm{O}_{2}$. The plateau current of each wave was plotted as a function of $\mathrm{H}_{2} \mathrm{O}_{2}$ concentration (see Figure S1). The response follows a linear evolution both in oxidation and reduction, providing good calibration curves for Pt-black UMEs in each potential domain. However, the slope is slightly lower in reduction, possibly because of two processes: the interference from phosphate anions, which adsorb on platinum and compete with other species; the formation of platinum oxides and their involvement in the oxidation process [41]. Nevertheless, both waves display similar current ranges for the same concentrations, showing that 2 electrons are involved in each electrochemical reaction. This is very unlikely, thermodynamically and kinetically, at physiological $\mathrm{pH}$ that 1e-reduction or oxidation processes occur. The proton concentration is sufficiently high to drive the reactions. Kinetically,

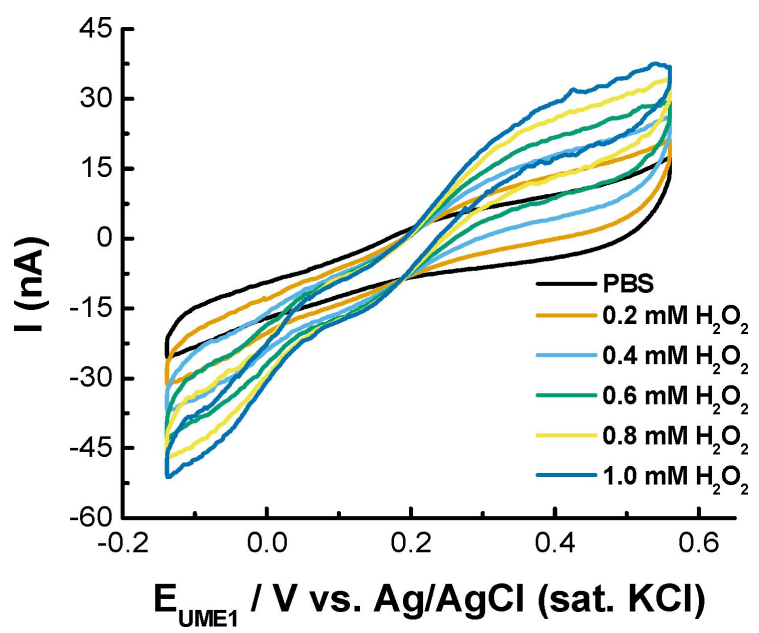

Fig. 2. Cyclic voltammetry responses of $\mathrm{H}_{2} \mathrm{O}_{2}$ solutions using Ptblack UMEs. $\mathrm{H}_{2} \mathrm{O}_{2}$ solutions from 0.2 to $1 \mathrm{mM}$ concentration are prepared in aerated physiological $\mathrm{PBS}$ at $\mathrm{pH}$ 7.4. Scan rate: $20 \mathrm{mVs}^{-1}$. hydroxyl radicals would not be stable enough to be observed, as well as for superoxide radical anions, which is demonstrated in the ensuing collector-generator experiments. In addition, $\mathrm{H}_{2} \mathrm{O}_{2}$ is a redox amphoteric species, thus the same diffusion coefficient applies for the reduction and oxidation reactions.

\subsubsection{Redox Behavior of $\mathrm{O}_{2}$}

The second set of experiments was designed to study the electroactivity of dioxygen on Pt-black UMEs in the potential range of hydrogen peroxide reactions. CV responses were recorded in PBS solutions containing different amounts of dissolved oxygen: either aerated, $\mathrm{N}_{2^{-}}$ or $\mathrm{O}_{2}$ - saturated. Results are presented on Figure 3.

A reduction wave, which starts at $0 \mathrm{~V}$ and is kinetically slow, appears when the PBS solution is saturated with $\mathrm{O}_{2}$, whereas $\mathrm{N}_{2}$-saturated PBS response shows solely the PBS background current (capacitive signal). The aerated PBS response shows an intermediate response, corresponding to the $220 \mu \mathrm{M}$ concentration of solubilized dioxygen in equilibrium in aerated solutions. The Oxygen Reduction Reaction (ORR) catalyzed by platinum-based electrodes is a well-studied reaction with a major focus on the products, being either $\mathrm{H}_{2} \mathrm{O}_{2}$ or $\mathrm{H}_{2} \mathrm{O}$ in aqueous solutions [42-45]. However, little is known about the ORR product on Pt-black surfaces, which have rarely been used for that purpose.

In this study, $\mathrm{H}_{2} \mathrm{O}_{2}$ and $\mathrm{O}_{2}$ are key species (mother or daughter species of superoxide anion). Therefore, it was necessary to know what the product of ORR $[46,47]$ in our experimental conditions is (PBS pH 7.4, Black-Pt UMEs). To do so, we designed a collector-generator experiment that aimed to detect in situ the product of ORR [48] (Figure 4). In this experiment, a reduction reaction and an oxidation reaction can be performed simultaneously but independently at the surface of two electrodes (Figure 4A). When the two electrodes are close enough, their respective diffusion layers overlap. It allows

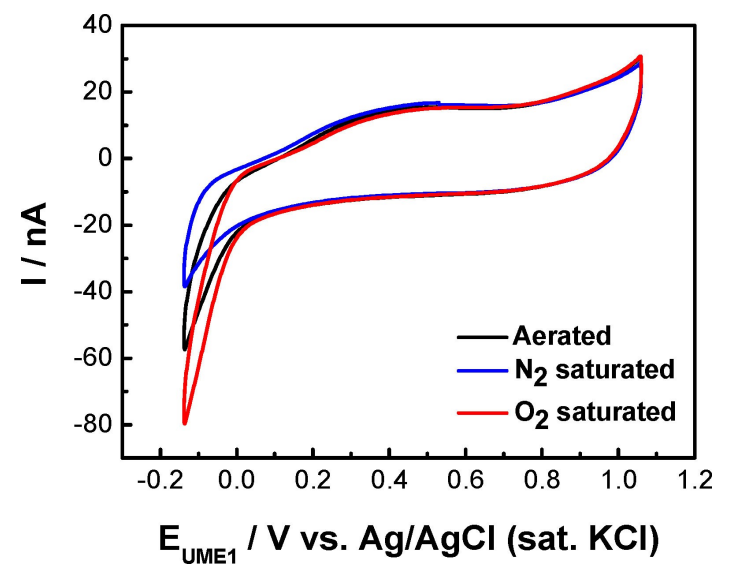

Fig. 3. Cyclic voltammetry responses on a Pt-black UME of aerated (black trace), $\mathrm{N}_{2}$ (blue trace) and $\mathrm{O}_{2}$ (red trace) saturated PBS solutions (10 mM, pH 7.4). Scan rate: $50 \mathrm{mV} \mathrm{s}^{-1}$. 

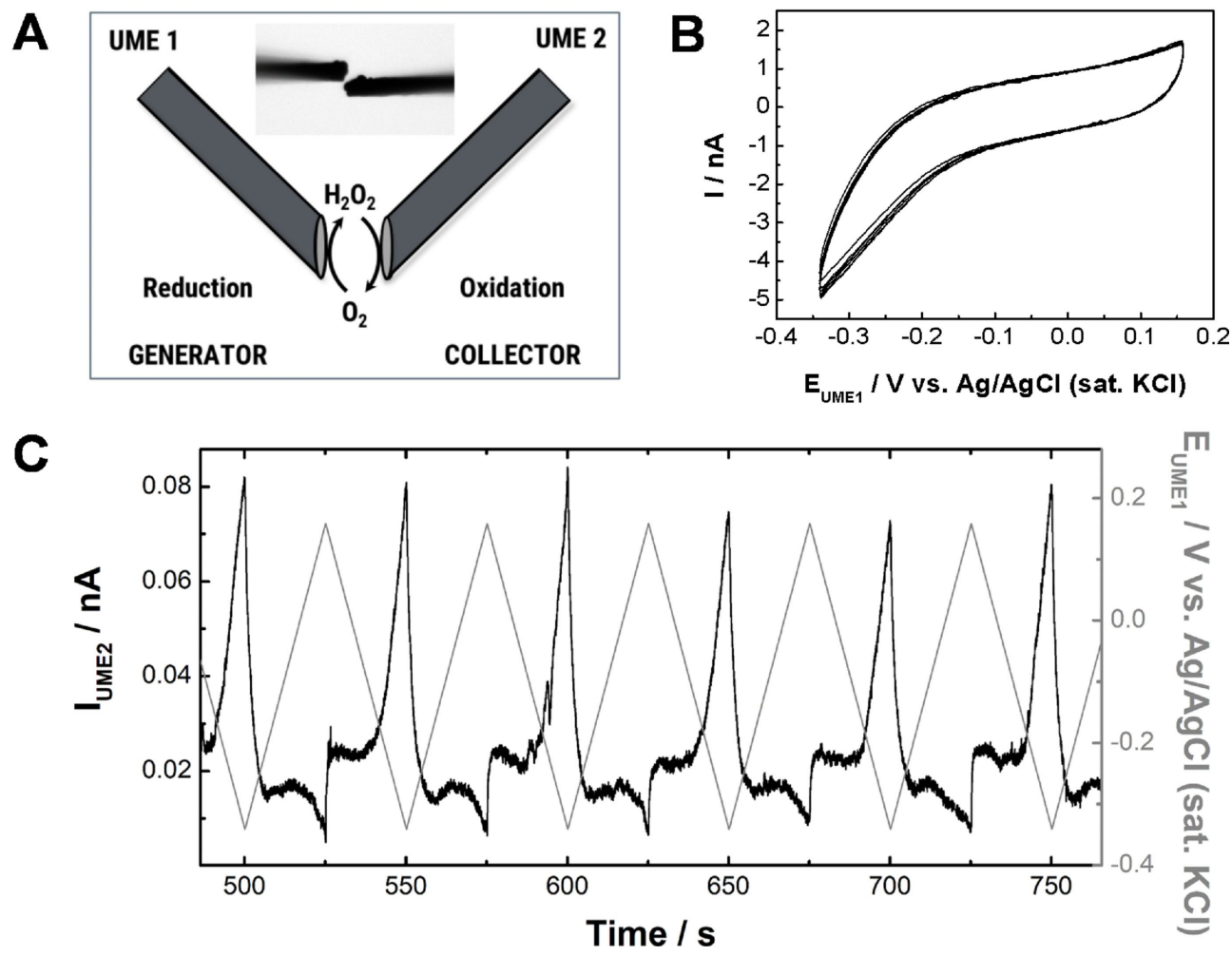

Fig. 4. A collector-generator experiment with two UMEs was performed to decipher on the ORR mechanism at Pt-black surfaces. A. Schematic representation describing the experiment principle. Inset: Image of the two electrodes used for the generator-collector experiment observed in transmitted light (bright field, inverted microscope). The distance between the two UMEs was set using two micromanipulators. B. Cyclic voltammogram of UME 1 at potentials varying between $+0.16 \mathrm{~V}$ to $-0.34 \mathrm{~V}$ (generator) at $50 \mathrm{mV} \mathrm{s}{ }^{-1}$. C. The induced current is recorded on UME 2 (black trace). The potential variations applied to the generator are displayed (dashed grey trace) to correlate with the collector signal.

the electro-generation of a species on one electrode (generator) that is detected on the other electrode (collector). Cyclic voltammetry measurements were made at $20 \mathrm{mV} \mathrm{s}^{-1}$, between $+0.16 \mathrm{~V}$ and $-0.34 \mathrm{~V}$ vs. $\mathrm{Ag} / \mathrm{AgCl}$, in order to reduce $\mathrm{O}_{2}$ on UME 1 (Figure 4A, left: generator), while current intensity variations were monitored by chrono-amperometry on UME 2 (Figure 4A, right: collector) at the oxidation potential of $\mathrm{H}_{2} \mathrm{O}_{2}(+$ $0.35 \mathrm{~V}$ vs. $\mathrm{Ag} / \mathrm{AgCl}$ ). The reduction wave detected on UME 1 is similar to the one observed in Figure 3 (Figure 4B). This process generates a species that is detected on UME 2, as shown by the simultaneous current variations (Figure 4C). The only candidate is $\mathrm{H}_{2} \mathrm{O}_{2}$ in comparison with our previous studies $[28,49,50]$.

Additionally, we confirmed that the species produced at UME 1 is effectively diffusing in solution before being detected at UME 2 by varying the distance between UME 1 and UME 2 (see Figure S2). In this experiment, both UME were set at a fixed potential: a continuous generation on UME 1 (chronoamperometry at $-0.34 \mathrm{~V}$ vs. $\mathrm{Ag} / \mathrm{AgCl}$ ) occurred simultaneously with a continuous collection on UME 2 (chronoamperometry at $+0.35 \mathrm{~V}$ vs. $\mathrm{Ag} / \mathrm{AgCl})$. When the distance between the two electrodes was about $1 \mu \mathrm{m}$, the current on UME 2 was maximum ( $0.03 \mathrm{nA}$ ) whereas it decreased drastically when the distance was superior to $10 \mu \mathrm{m}(\sim 0.015 \mathrm{nA}$, i. e. close to the background current). Indeed, the diameter of the electrode being of $25 \mu \mathrm{m}$, the size of the diffusion layer is about $10-15 \mu \mathrm{m}$ (in the Nernst approximation). Therefore, the species produced by the reduction of $\mathrm{O}_{2}$ on UME 1 is no longer detected on UME 2. Overall, the collector-generator experiments demonstrated that $\mathrm{H}_{2} \mathrm{O}_{2}$ is the major product of the $\mathrm{O}_{2}$ reduction reaction on Ptblack electrodes at physiological pH (PBS, pH 7.4).

\subsubsection{Redox Behavior of $\mathrm{H}_{2} \mathrm{O}_{2}$ and $\mathrm{O}_{2}$ Mixture}

From results depicted on Figures 2 and 3, we observe that both $\mathrm{O}_{2}$ and $\mathrm{H}_{2} \mathrm{O}_{2}$ are reduced on Pt-black electrodes at similar potentials, below $0 \mathrm{~V}$ vs. $\mathrm{Ag} / \mathrm{AgCl}$. As these two species should be produced together during superoxide disproportionation (Equation 1), we studied how they could possibly be discriminated. To answer this question, cyclic voltammetry experiments were realized in $\mathrm{N}_{2}$ and $\mathrm{O}_{2}$-saturated $\mathrm{H}_{2} \mathrm{O}_{2}$ solutions $(1 \mathrm{mM})$ between $-0.2 \mathrm{~V}$ and $+0.5 \mathrm{~V}$ (Figure 5).

When the $\mathrm{H}_{2} \mathrm{O}_{2}$ solution was saturated with dioxygen, the reduction current increased compared to the $\mathrm{N}_{2}$ saturated one. It is clear from these curves that the reduction wave of oxygen superimposes with the one of 


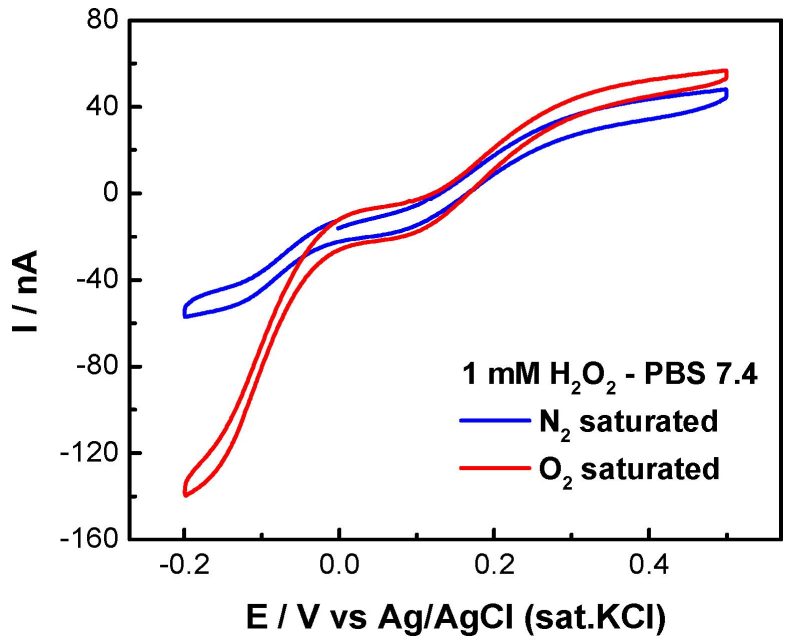

Fig. 5. Cyclic voltammetry responses on Pt-black UMEs of $\mathrm{N}_{2-}$ (blue trace) and $\mathrm{O}_{2^{-}}$(red trace) saturated $\mathrm{H}_{2} \mathrm{O}_{2}$ solutions $(1 \mathrm{mM})$ prepared in PBS (10 mM, pH 7.4). Scan rate: $20 \mathrm{mV} \mathrm{s}^{-1}$.

hydrogen peroxide, though a slight shift may be distinguished; the plateau potential for $\mathrm{O}_{2}$ is observed $\sim 30 \mathrm{mV}$ further than the one of $\mathrm{H}_{2} \mathrm{O}_{2}$. Nevertheless, the total faradaic current at $-0.2 \mathrm{~V}$ is indeed the sum of at least the two reduction currents of hydrogen peroxide and dioxygen. Consequently, the two species cannot be discriminated based solely on electro-reduction responses although figure 5 shows also that in the potential range of $+0.1 \mathrm{~V}$ and $+0.5 \mathrm{~V}$, the oxidation current is specific to $\mathrm{H}_{2} \mathrm{O}_{2}$. Finally, the electroactivities of $\mathrm{H}_{2} \mathrm{O}_{2}$ and $\mathrm{O}_{2}$ on Ptblack UMEs are intimately related but hard to discriminate upon their reduction waves unless the solution would be analyzed before and after degassing (nitrogen or argon).

\subsection{Redox Behavior of Superoxide at $\mathrm{pH} 12$ and its Fate at $\mathrm{pH} 7.4$}

The next step consisted in studying the response of Ptblack UMEs towards superoxide anion itself. As described in the experimental section, $\mathrm{O}_{2}{ }^{--}$was prepared by solubilizing $\mathrm{KO}_{2}$ salt in alkaline phosphate buffer ( $\left.\mathrm{pH} 12\right)$ in order to stabilize it and therefore facilitate its electrochemical study. Cyclic voltammetry experiments were thus performed in $5 \mathrm{mM}$ superoxide basic solutions (10 mM PBS, pH 12) (Figure 6).

The superoxide anion voltammogram shows a welldefined electrochemical reversible signal on Pt-black surface, which is centered at $\mathrm{E}^{\bullet}=-0.085 \mathrm{~V}$ vs $\mathrm{Ag} / \mathrm{AgCl}$ and follows the redox equation (Equation $4, \mathrm{O}_{2} / \mathrm{O}_{2}{ }^{\cdot-}$ redox couple):

$$
\mathrm{O}_{2}^{\cdot-} \leftrightarrow \mathrm{O}_{2}+e^{-}
$$

The dependence between the detected electrochemical wave and the superoxide species was further demonstrated by studying the evolution of this response in $\mathrm{CV}$

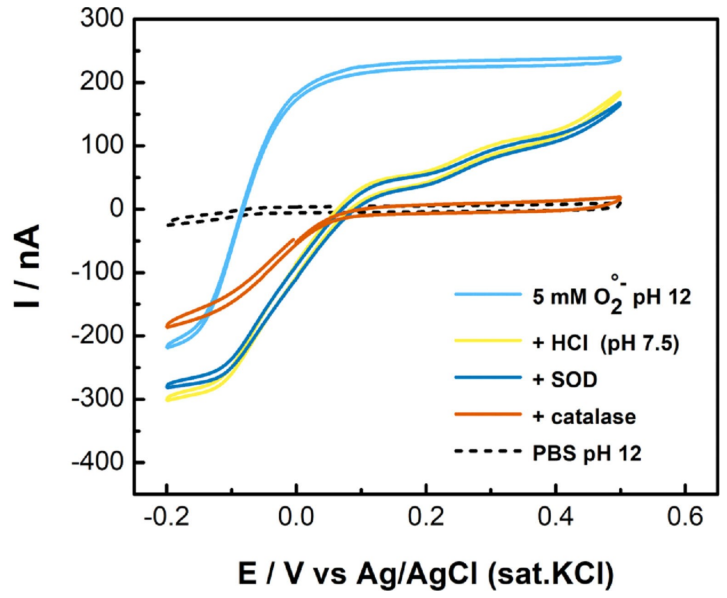

Fig. 6. Evolution of the cyclic voltammetry response (on Pt-black UMEs) in a superoxide basic solution (blue trace, $\mathrm{t}=0$ ), when $\mathrm{pH}$ is changed to physiological values (yellow trace), followed by SOD (55 $\mathrm{U} \mathrm{mL}^{-1}$ final, purple trace, $\mathrm{t}=13 \mathrm{~min}$ ) and catalase (> $100 \mathrm{U} \mathrm{mL}^{-1}$ final, orange trace, $\mathrm{t}=17 \mathrm{~min}$ ) additions. Scan rate: $20 \mathrm{mVs}^{-1}$.

as function of the $\mathrm{pH}$. We first recorded successive CVs in a $5 \mathrm{mM}$ superoxide solution in phosphate buffer at $\mathrm{pH} 12$ for nearly $30 \mathrm{~min}\left(40\right.$ cycles at $\left.20 \mathrm{mV} \mathrm{s}^{-1}\right)$. A progressive decrease of the wave amplitude was observed (see Figure S3A) even in such basic conditions. $\mathrm{O}_{2}{ }^{--}$disproportionates (Equation 1) into dioxygen and hydroperoxide anion $\left(\mathrm{HO}_{2}^{-}\right.$, the basic form of $\left.\mathrm{H}_{2} \mathrm{O}_{2}\right)$. We performed in parallel a similar experiment in a phosphate buffer solution at $\mathrm{pH} 12$ containing only the hydroperoxide anion and observed that the loss of response was more important for the $\mathrm{O}_{2}{ }^{--}$solution $(\sim 35 \%)$ than for $\mathrm{HO}_{2}^{-}$at $\mathrm{pH} 12$ ( 3\%; Figure S3B), as $\mathrm{HO}_{2}^{-}$does not follow the disproportionation reaction of $\mathrm{O}_{2}{ }^{--}$.

This observation was reinforced by switching rapidly the $\mathrm{pH}$ of a $5 \mathrm{mM} \mathrm{O}_{2}{ }^{\bullet-}$ solution from 12 to $\sim 7.4$, as shown on Figure 6. The evolution was monitored by $\mathrm{CV}$ in a potential window where all the different species can be detected, i.e. $-0.2 \mathrm{~V}$ to $+0.5 \mathrm{~V}$. The $\mathrm{pH}$ of the superoxide solution was shifted from $\mathrm{pH} 12$ (blue trace) to physiological values $(\sim 7.4-7.6)$ by additions of concentrated $\mathrm{HCl}$ (yellow trace). It led to an increase of the reduction current, due to the appearance of $\mathrm{O}_{2}$ and $\mathrm{H}_{2} \mathrm{O}_{2}$ formed by the $\mathrm{O}_{2}{ }^{--}$decomposition (see Equation 1), while the oxidative current decreased and displayed the oxidation wave of $\mathrm{H}_{2} \mathrm{O}_{2}$ observed previously (Figure 2). In order to confirm that no more superoxide remained in the solution, SOD (55 U.mL ${ }^{-1}$ final) was added. A very slight increase of reduction and oxidative currents were noticed (purple trace, to be compared with the yellow one), revealing that the major part of superoxide had disproportionated just after the $\mathrm{pH}$ change. The shapes of the yellow and purple curves are similar to the one corresponding to an $\mathrm{O}_{2}$-saturated $\mathrm{H}_{2} \mathrm{O}_{2}$ solution, as described in Figure 5 (red trace). Thus, at this end stage of the 
experiment, $\mathrm{H}_{2} \mathrm{O}_{2}$ and $\mathrm{O}_{2}$ should be the only species present in solution.

To verify this later assumption, catalase was added to the solution in order to consume $\mathrm{H}_{2} \mathrm{O}_{2}$ (orange trace). Compared with the purple trace, the oxidative current due to $\mathrm{H}_{2} \mathrm{O}_{2}$ oxidation is vanished and the reduction current is decreased leading to a reduction wave attributable to dioxygen (orange trace). Indeed, $\mathrm{H}_{2} \mathrm{O}_{2}$ was consumed by the catalase producing a stoichiometric amount of $\mathrm{O}_{2}$ that is reduced at low potentials (see Figures 3 and 5). Overall, this set of experiments unambiguously demonstrates that the reversible wave detected initially at $\mathrm{pH} 12$ is due to superoxide anion.

Moreover, since the electrochemical reaction (equation 4) corresponding to this wave does not involve any proton, superoxide might be detected at the same potentials, with the same Pt-black surfaces, regardless of $\mathrm{pH}$, assuming that the species is sufficiently chemically stable to be detected by $\mathrm{CV}$. When considering the results reported above about the electrochemical responses of superoxide and its relatives, dioxygen and hydrogen peroxide, we may figure out how to discriminate one from the others as a function of the potential window, in particular at $\mathrm{pH}$ 7.4. We observed that at potentials below $-0.1 \mathrm{~V}$, all three species are reduced on Pt-Black UMEs and cannot actually be discriminated from their $\mathrm{CV}$ response. Nevertheless, the addition of scavengers and enzymes (SOD, catalase) would allow to make a decision since the only species remaining after enzymatic conversions is $\mathrm{O}_{2}$. However, as shown on Figures 2, 5 and 6, at neutral potential, i.e. between 0 and $+0.1 \mathrm{~V}$, hydrogen peroxide and oxygen are not detected, only a background current is observed (with slightly negative current values due to the reduction of platinum oxides). Therefore, we can assume that an oxidation current between $0 \mathrm{~V}$ and $+0.1 \mathrm{~V}$ recorded at $\mathrm{pH} 7.4$ would only correspond to superoxide (if produced in sufficient amount). At higher potentials, above $+0.1 \mathrm{~V}$, up to $+0.5 \mathrm{~V}$ herein, $\mathrm{O}_{2}{ }^{--}$and $\mathrm{H}_{2} \mathrm{O}_{2}$ can be both detected meaning that the oxidation current due to $\mathrm{H}_{2} \mathrm{O}_{2}$ would add to the plateau current of the superoxide oxidation wave already detected at +0.1 V. Consequently, as function of the CV shape and current amplitudes in the range of positive potentials, we might be able to decipher on the contributions of $\mathrm{O}_{2}{ }^{--}$ and $\mathrm{H}_{2} \mathrm{O}_{2}$.

This set of analyses opens avenues for the detection of superoxide in aqueous solutions treated by CAPs, for two reasons: 1/ superoxide has already been detected indirectly in plasma-treated solutions [51,52]) and is present transitorily at high concentrations; 2/ CAPs are considered as a source of superoxide (and other RONS) which dissolve at the interface between the gas phase and the liquid solution and does not change significantly the $\mathrm{pH}$ of the PBS [19], contrary to the release of superoxide in PBS using the $\mathrm{KO}_{2}$ source.

In this context, we recently reported [21] the results of in situ measurements, with shielded Pt-black UMEs, of species accumulating in PBS exposed to a CAP. We observed in PBS pH 7.4 the progressive appearance of chemically stable species, namely $\mathrm{H}_{2} \mathrm{O}_{2}$ and $\mathrm{NO}_{2}{ }^{-}$, as well as the rise of an oxidation wave and current near $0 \mathrm{~V}$ vs $\mathrm{Ag} / \mathrm{AgCl}$. This species was detected after long exposure durations (typically $30 \mathrm{~min}$.) of the PBS corresponding to its accumulation and increase of its net flux versus reactions involved in its disappearance. The same experiment was performed in PBS at $\mathrm{pH} 11$, a condition which increases superoxide stability and should favor its steadystate detection. In situ monitoring of $\mathrm{O}_{2}{ }^{--}$along its generation and accumulation was performed with a shielded Pt-black UME during the solution exposure to a He CAP (see material and methods for details about the setup). As shown in Figure 7, a reversible wave appears after $20 \mathrm{~min}$. and rises in amplitude over the exposure duration. The wave, e.g. detected at $26 \mathrm{~min}$., is very similar in characteristics to the one detected in Figure 6 with the same WE in a solution supplied with the superoxide species. This demonstrates the in situ detection of $\mathrm{O}_{2}{ }^{--}$, which concentration at this time point can be estimated to reach about $400 \mu \mathrm{M}$. Moreover, the chemical evolution of superoxide solutions, as discussed above, was also observed in the exposed PBS since a second wave that can very likely be attributed to $\mathrm{H}_{2} \mathrm{O}_{2}$ was observed after $30 \mathrm{~min}$. The kinetic evolutions of exposed PBS solutions at $\mathrm{pH} 11$ were slower, as expected, than what was observed recently at $\mathrm{pH} 7.4$ [21]. Finally, based on the set of studies reported herein, we draw the conclusion that the species detected in CAP-treated PBS might be superoxide anion. No other RONS (including $\mathrm{H}_{2} \mathrm{O}_{2}, \mathrm{NO}^{*}$, $\mathrm{ONOO}^{-}, \mathrm{HNO}$ and $\mathrm{NO}_{2}^{-}$) has shown the same electrochemical and chemical features, particularly when detected with Pt-black modified electrodes.

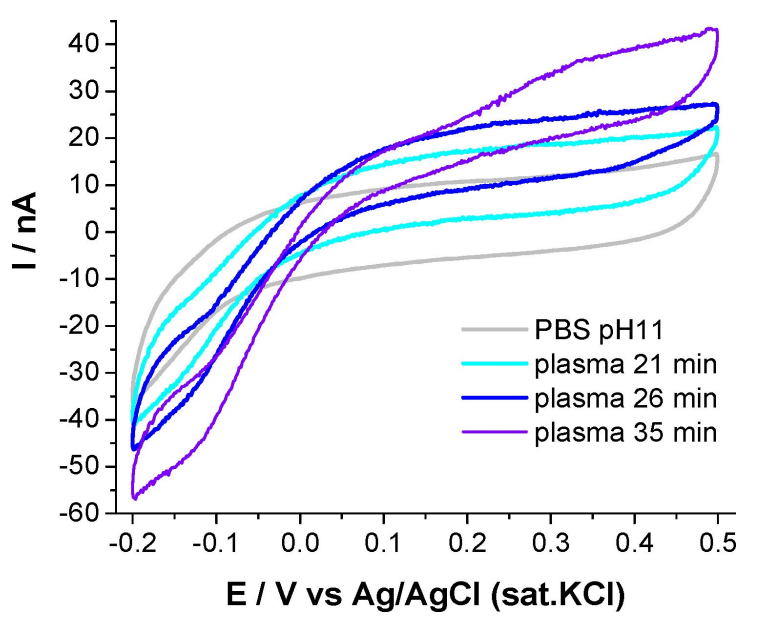

Fig. 7. Evolution of the cyclic voltammetry response in a PBS solution at $\mathrm{pH} 11$ (gray trace, $\mathrm{t}=0$ ), along its exposure to a cold atmospheric plasma (He working gas; $100 \% \mathrm{~N}_{2}$ environment). Measurements were performed directly, in situ $(6 \mathrm{~mL}$ cell volume), with a shielded-grounded electrochemical cell (Pt-black UME, REF and CE placed in shielded tubes). Scan rate: $20 \mathrm{mV} \mathrm{s}^{-1}$. 


\section{Conclusions}

In this study, we analyzed the redox behavior of $\mathrm{O}_{2}{ }^{--}$in a physiological phosphate-buffered saline (PBS) solution, the most commonly used in bioanalyses. As superoxide is not stable and rapidly disproportionates into $\mathrm{H}_{2} \mathrm{O}_{2}$ and $\mathrm{O}_{2}$, it was necessary to decipher on the reactivity of Ptblack UMEs towards these species when they are mixed in solution. We showed that $\mathrm{H}_{2} \mathrm{O}_{2}$ has a clear redox signature in both oxidation and reduction. Nevertheless, since $\mathrm{O}_{2}$ is naturally dissolved in solution when working in open environment, the detection by reduction of $\mathrm{H}_{2} \mathrm{O}_{2}$ appeared to be more complex because its wave overlaps with the one of $\mathrm{O}_{2}$ reduction. Moreover, we showed that the ORR at Pt-Black ( $\mathrm{pH} 7.4)$ is a 2 electrons and $2 \mathrm{H}^{+}$ process leading to $\mathrm{H}_{2} \mathrm{O}_{2}$. Thus, oxygen cannot be specifically measured by Pt-black UMEs if hydrogen peroxide is present. However, we have identified that $\mathrm{H}_{2} \mathrm{O}_{2}$ can be selectively detected with Pt-black UMEs in the potential range of $+0.1 \mathrm{~V}$ to $+0.5 \mathrm{~V}$ owing to its first oxidation wave.

The redox response of superoxide on Pt-black UMEs was studied first in alkaline conditions, which favors its stabilization, and then in physiological conditions by changing the $\mathrm{pH}$ of the solution. Despite the presence of $\mathrm{H}_{2} \mathrm{O}_{2}$ and $\mathrm{O}_{2}$ in solutions at both $\mathrm{pH} 7.4$ and 12 , we have identified that $0 \mathrm{~V}$ (no overpotential vs $\mathrm{Ag} / \mathrm{AgCl}$ ) is an adequate potential to specifically detect superoxide by Ptblack UMEs based on its oxidation response, regardless of $\mathrm{pH}$. This result opens a range of possibilities concerning the electroanalysis of $\mathrm{O}_{2}{ }^{--}$in physiological conditions, for instance when produced by cells in NAPDH oxidasedependent activities, as well as for biomedical applications of Cold Atmospheric Plasmas (CAPs) produced in air.

\section{Acknowledgements}

This work was financially supported by the Centre National de la Recherche Scientifique (CNRS), the French Ministry of Research (MESR) and the Agence Nationale de la Recherche (ANR, PLASMAREGEN project, no. ANR-14-CE16-0007-01).

\section{Data Availability Statement}

Data sharing is not applicable to this article as no new data were created or analyzed in this study.

\section{References}

[1] H. Sies, D. Jones, Nat. Rev. Mol. Cell Biol. 2020, 21, 363383.

[2] I. Liguori, G. Russo, F. Curcio, G. Bulli, L. Aran, D. DellaMorte, G. Gargiulo, G. Testa, F. Cacciatore, D. Bonaduce, P. Abete, Clin. Interventions Aging 2018, 13, 757-772.

[3] A. Singh, R. Kukreti, L. Saso, S. Kukreti, Molecules 2019 , $24,1583$.
[4] D. Camejo, Á. Guzmán-Cedeño, A. Moreno, Plant Physiol. Biochem. 2016, 103, 10-23.

[5] J. Navarro-Yepes, M. Burns, A. Anandhan, O. Khalimonchuk, L. M. del Razo, B. Quintanilla-Vega, A. Pappa, M. I. Panayiotidis, R. Franco, Antioxid. Redox Signaling 2014, 21, 66-85.

[6] G. V. Buxton, C. L. Greenstock, W. P. Helman, A. B. Ross, J. Phys. Chem. Ref. Data 1988, 17, 513-886.

[7] A. A. Noronha-Dutra, M. M. Epperlein, N. Woolf, FEBS Lett. 1993, 321, 59-62.

[8] M. Valko, K. Jomova, C. J. Rhodes, K. Kuča, K. Musílek, Arch. Toxicol. 2016, 90, 1-37.

[9] M. E. Letelier, S. Sánchez-Jofré, L. Peredo-Silva, J. CortésTroncoso, P. Aracena-Parks, Chem.-Biol. Interact. 2010, 188, 220-227.

[10] P. Pacher, J. S. Beckman, L. Liaudet, Physiol. Rev. 2007, 87, 315-424.

[11] C. Szabó, H. Ischiropoulos, R. Radi, Nat. Rev. Drug Discovery 2007, 6, 662-680.

[12] A. Privat-Maldonado, A. Schmidt, A. Lin, K.-D. Weltmann, K. Wende, A. Bogaerts, S. Bekeschus, Oxid. Met. 2019, 2019, 1-29.

[13] S. O. Ganiyu, M. Zhou, C. A. Martínez-Huitle, Appl. Catal. B 2018, 235, 103-129.

[14] S. Di Meo, T. T. Reed, P. Venditti, V. M. Victor, Oxid. Met. 2016, 2016, 1-3.

[15] N. K. Kaushik, B. Ghimire, Y. Li, M. Adhikari, M. Veerana, N. Kaushik, N. Jha, B. Adhikari, S.-J. Lee, K. Masur, T. von Woedtke, K.-D. Weltmann, E. H. Choi, Biol. Chem. 2018, 400, 39-62.

[16] R. Thirumdas, A. Kothakota, U. Annapure, K. Siliveru, R. Blundell, R. Gatt, V. P. Valdramidis, Trends Food Sci. Technol. 2018, 77, 21-31.

[17] K.-D. Weltmann, T. von Woedtke, Plasma Phys. Controlled Fusion 2017, 59, 014031.

[18] X. Chen, F. Wang, J. Y. Hyun, T. Wei, J. Qiang, X. Ren, I. Shin, J. Yoon, Chem. Soc. Rev. 2016, 45, 2976-3016.

[19] F. Girard, V. Badets, S. Blanc, K. Gazeli, L. Marlin, L. Authier, P. Svarnas, N. Sojic, F. Clément, S. Arbault, RSC Adv. 2016, 6, 78457-78467.

[20] F. Girard, M. Peret, N. Dumont, V. Badets, S. Blanc, K. Gazeli, C. Noël, T. Belmonte, L. Marlin, J.-P. Cambus, G. Simon, N. Sojic, B. Held, S. Arbault, F. Clément, Phys. Chem. Chem. Phys. 2018, 20, 9198-9210.

[21] F. Girard-Sahun, V. Badets, P. Lefrançois, N. Sojic, F. Clement, S. Arbault, Anal. Chem. 2019, 91, 8002-8007.

[22] C. Calas-Blanchard, G. Catanante, T. Noguer, Electroanalysis 2014, 26, 1277-1286.

[23] E. Suraniti, S. Ben-Amor, P. Landry, M. Rigoulet, E. Fontaine, S. Bottari, A. Devin, N. Sojic, N. Mano, S. Arbault, Angew. Chem. 2014, 126, 6773-6776; Angew. Chem. Int. Ed. 2014, 53, 6655-6658.

[24] P. Manning, C. J. McNeil, Biochem. Soc. Trans. 2011, 39, 1288-1292.

[25] F. Bedioui, D. Quinton, S. Griveau, T. Nyokong, Phys. Chem. Chem. Phys. 2010, 12, 9976.

[26] S. Gáspár, J. L. Marty, E. Gheorghiu, Electroanalysis 2013 , $25,448-452$.

[27] C. Amatore, S. Arbault, A. C. W. Koh, Anal. Chem. 2010, $82,1411-1419$.

[28] C. Amatore, S. Arbault, C. Bouton, J.-C. Drapier, H. Ghandour, A. C. W. Koh, ChemBioChem 2008, 9, 14721480.

[29] C. Amatore, S. Arbault, Y. Bouret, B. Cauli, M. Guille, A. Rancillac, J. Rossier, ChemPhysChem 2006, 7, 181-187. 
[30] C. Amatore, S. Arbault, D. Bruce, P. De Oliveira, M. Erard, M. Vuillaume, Chem. Eur. J. 2001, 7, 4171-4179.

[31] R. Hu, M. Guille, S. Arbault, C. J. Lin, C. Amatore, Phys. Chem. Chem. Phys. 2010, 12, 10048-10054.

[32] L. Xiang, P. Yu, M. Zhang, J. Hao, Y. Wang, L. Zhu, L. Dai, L. Mao, Anal. Chem. 2014, 86, 5017-5023.

[33] Y. Li, A. Meunier, R. Fulcrand, C. Sella, C. Amatore, L. Thouin, F. Lemaître, M. Guille-Collignon, Electroanalysis 2016, 28, 1865-1872.

[34] Y. Li, C. Sella, F. Lemaître, M. Guille Collignon, L. Thouin, C. Amatore, Electroanalysis 2013, 25, 895-902.

[35] Y. Li, C. Sella, L. Thouin, Anal. Chem. 2018, 9.

[36] Y. Li, C. Sella, F. Lemaître, M. Guille-Collignon, L. Thouin, C. Amatore, Electrochim. Acta 2014, 144, 111-118.

[37] V. Badets, J. Pandard, N. Sojic, S. Arbault, ChemElectroChem 2016, 3, 2288-2296.

[38] S. Marklund, J. Biol. Chem. 1976, 251, 7504-7507.

[39] S. Ben-Amor, E. Vanhove, F. Sékli Belaïdi, S. Charlot, D. Colin, M. Rigoulet, A. Devin, N. Sojic, J. Launay, P. Temple-Boyer, S. Arbault, Electrochim. Acta 2014, 126, 171178.

[40] K. T. Kawagoe, J. A. Jankowski, R. Mark. Wightman, Anal. Chem. 1991, 63, 1589-1594.

[41] I. Katsounaros, W. B. Schneider, J. C. Meier, U. Benedikt, P. U. Biedermann, A. A. Auer, K. J. J. Mayrhofer, Phys. Chem. Chem. Phys. 2012, 14, 7384.

[42] X. Cai, E. E. L. Tanner, C. Lin, K. Ngamchuea, J. S. Foord, R. G. Compton, Phys. Chem. Chem. Phys. 2018, 20, 16081614.
[43] I. Katsounaros, W. B. Schneider, J. C. Meier, U. Benedikt, P. U. Biedermann, A. A. Auer, K. J. J. Mayrhofer, Phys. Chem. Chem. Phys. 2012, 14, 7384-7391.

[44] C. H. Choi, H. C. Kwon, S. Yook, H. Shin, H. Kim, M. Choi, J. Phys. Chem. C 2014, 118, 30063-30070.

[45] Y. Jiang, P. Ni, C. Chen, Y. Lu, P. Yang, B. Kong, A. Fisher, $\mathrm{X}$. Wang, Adv. Energy Mater. 2018, 8, 1801909.

[46] Md. T. Islam, Md. M. Hasan, Md. F. Shabik, F. Islam, Y. Nagao, M. A. Hasnat, Electrochim. Acta 2020, 360, 136966.

[47] Md. S. Hossain, M. Y. A. Mollah, Md. A. B. H. Susan, Md. M. Islam, Electrochim. Acta 2020, 344, 136146.

[48] M. A. Hasnat, A. J. Gross, S. E. C. Dale, E. O. Barnes, R. G. Compton, F. Marken, The Analyst 2014, 139, 569-575.

[49] V. Badets, J. Pandard, N. Sojic, S. Arbault, ChemElectroChem 2016, 3, 2288-2296.

[50] C. Amatore, S. Arbault, C. Ducrocq, S. Hu, I. Tapsoba, ChemMedChem 2007, 2, 898-903.

[51] J. Chauvin, F. Judée, M. Yousfi, P. Vicendo, N. Merbahi, Sci. Rep. 2017, 7, DOI 10.1038/s41598-017-04650-4.

[52] A. Khlyustova, C. Labay, Z. Machala, M.-P. Ginebra, C. Canal, Front. Chem. 2019, 13, 238-252. 
A

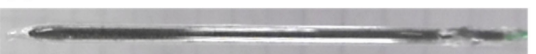

B

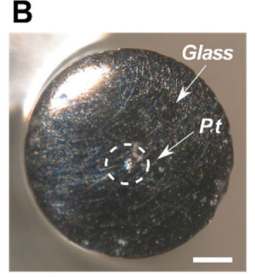

P. Lefrançois, F. Girard-Sahun, $V$.

Badets, F. Clément, S. Arbault*

$1-10$

Electroactivity of Superoxide Anion in Aqueous Phosphate Buffers Analyzed with Platinized Microelectrodes 